\title{
The Development of Reading Textbook Oriented to Character Education using Multimodality in College
}

\author{
Sesmiyanti' ${ }^{1}$ Rindilla Antika², Suharni3 ${ }^{3}$
}

DOI: $10.35445 /$ alishlah.v13i1.436

Info Artikel Abstract

Keywords:

Basic Reading, Character Education, Textbook

Kata kunci:

Buku Ajar, Basic

Reading, Pendidikan Karakter

\begin{abstract}
This research aims to develop a textbook for the Basic Reading subject by using multimodality and oriented to character education. This research is research and development, which refers to the ADDIE model (Analysis, Design, Develop, Implementation, and Evaluation). Subjects of this research are students and lecturers who have taken part in the Basic Reading subject at English Education Department STKIP PGRI Sumatera Barat. Data collection techniques used are document analysis, questionnaire, interview, and expert judgments. The results of need analysis show that the textbook used in Basic Reading subject has not oriented to character education and used multimodality yet. The development of Basic Reading has been validated by education experts and practitioners (lecturers). Based on the validation of experts and practitioners, this textbook is included in the very well category and confirmed as the feasibility to use. The trial results in implementing the book show that the N-Gain calculation shows 0.43 , which is categorized as moderate, which means the book improves students' cognitive learning outcomes in the reading subject and also instills core ethical values in daily living. Thus, this textbook is feasible to be used in the learning process at Basic Reading Subject.
\end{abstract}

\begin{abstract}
Abstrak
Penelitian ini bertujuan untuk mengembangkan buku ajar pada mata kuliah Basic Reading yang menggunakan multimodality dan berorientasi pada pendidikan karakter. Penelitian ini merupakan penelitian dan pengembangan yang mengacu pada pola pengembangan ADDIE (Analysis, Design, Develop, Implementation, and Evaluation). Subjek pada penelitian ini adalah mahasiswa dan dosen yang telah mengikuti mata kuliah Basic Reading di prodi Pendidikan Bahasa Inggris STKIP PGRI Sumatera Barat. Teknik pengumpulan data yang digunakan adalah analisa dokumen, kuisioner, wawancara dan validasi tim ahli. Berdasarkan hasil analisa kebutuhan diketahui bahwa buku ajar yang digunakan pada mata kuliah Basic Reading belum berorientasi pada pendidikan karakter dan belum menggunakan multimodality. Pengembangan buku ajar Basic Reading ini telah divalidasi oleh ahli pendidikan dan praktisi. Berdasarkan validasi oleh tim ahli dan praktisi ini, buku ajar Basic Reading ini termasuk sangat baik dan layak untuk diujicobakan. Hasil ujicoba
\end{abstract}

${ }^{1}$ STKIP PGRI Sumatera Barat, Padang, Indonesia

Email: sesmiyantiog@gmail.com

${ }^{2}$ STKIP Nasional, Padang Pariaman, Indonesia

Email:dillarindilla@gmail.com

3 STKIP PGRI Sumatera Barat, Padang, Indonesia

Email: suharnithalib5@gmail.com 
menunjukkan bahwa kalkulasi N-Gain menunjukkan nilai o,43 dengan kategori sedang yang menunjukkan bahwa buku ajar ini dapat meningkatkan pengetahuan mahasiswa dalam pembelajaran reading dan juga menanamkan nilai karakter pada kehidupan sehari - hari. Dengan demikian, buku ajar ini layak untuk digunakan dalam proses perkuliahan pada mata kuliah Basic Reading.

\section{PENDAHULUAN}

Pendidikan karakter telah menjadi tujuan pendidikan nasional. Pendidikan nasional bertujuan untuk mengembangkan kualitas kepribadian bangsa Indonesia yang tercantum dalam standar pendidikan sehingga pendidikan nasional menjadi tonggak pembentuk karakter bangsa (Jalil, 2016).Karakter sering dikaitkan dengan temperamen seseorang yang ditekankan pada unsur psikososial yang dikaitkan dengan konteks lingkungan dan pendidikan. Pendidikan karakter dimaknai sebagai pendidikan nilai, budi pekerti, pendidikan moral dan watak yang bertujuan untuk mengembangkan kemampuan peserta didik untuk mewujudkan kebaikan dalam kehidupan sehari - hari dengan sepenuh hati untuk membentuk penyempurnaan diri individu secara terus - menerus dan melatih kemampuan diri demi menuju kearah hidup yang lebih baik (Jalil, 2016). Hal ini sejalan dengan pengertian karakter yang didefinisikan oleh Kementerian Pendidikan Nasional (Pawitasari et al., 2015) yaitu sebuah bawaan hati, jiwa, kepribadian, budi pekerti, perilaku, personalitas, sifat, tabiat, temperamen, dan watak. Seseorang dikatakan berkarakter apabila mempunyai kepribadian, perilaku, sifat, tabiat, dan watak yang mulia. Dengan kata lain, karakter mulia mempunyai makna individu yang memiliki pengetahuan tentang potensi dirinya, yang ditandai dengan nilai-nilai positif seperti reflektif, percaya diri, rasional, logis, kritis, analitis, kreatif dan inovatif, mandiri, bertanggung jawab, cinta ilmu, dan lainnya (Palila, 2012).

Pendidikan karakter merupakan sebuah proses kontiniu yang harus terintegrasi dengan pendidikan dengan aspek seperti kognitif, afektif, konatif, dan psikomotorik yang harus dikembangkan secara holistik dalam konteks kultural. Dengan demikian, dapat dikatakan bahwa karakter mempunyai peran yang sangat penting dalam pendidikan sehingga tujuan penyelenggaraan pendidikan adalah untuk mewujudkan peserta didik yang bermartabat dan memiliki karakter moral yang mulia (Putri, 2011). Selain itu, tujuan pendidikan nasional pada dasarnya membentuk karakter yang baik dalam diri peserta didik sehingga dapat menghasilkan masyarakat yang cerdas dan berkarakter kuat. Dengan demikian, pengertian pendidikan secara tersirat bermuatan pendidikan karakter dengan menanamkan unsur pengetahuan (kognitif), nilai sikap, (afektif), dan cara berperilaku (psikomotorik) kepada peserta didik (Kuswono, 2013).

Berdasarkan hal tersebut, maka STKIP PGRI Sumatera Barat mengembangkan kurikulum berbasis KKNI dimana pada setiap mata kuliah harus mempunyai capaian pembelajaran berbasis softskills. Hal ini terlihat pada capaian kompetensi yang didalamnya terdapat komponen seperti kompetensi pedagogik, kompetensi professional, kompetensi sosial, dan kompetensi sikap. Pada kompetensi pedagogik dan kompetensi professional, mahasiswa dituntut untuk memiliki kemampuan hardskills sesuai dengan program studinya. Sedangkan pada kompentensi sosial dan sikap, mereka dituntut untuk memiliki kemampuan softskillsserta keterampilan intrapersonal dan interpersonal.

Akan tetapi, pendidikan karakter ini belum tergambar pada proses pembelajaran di perguruan tinggi khususnya di prodi Pendidikan Bahasa Inggris STKIP PGRI Sumatera Barat. Pembelajaran adalah interaksi yang terjadi antara peserta didik dengan lingkungan belajarnya baik itu lingkungan kelas, sekolah, maupun lingkungan masyarakat (Hidayah et al., 2017). Keberhasilan sebuah proses belajar ditentukan oleh lingkungan belajarnya sehingga harus dirancang dan dikelola dengan baik dalam mengembangkan pengetahuan, keterampilan, dan sikap peserta didik. Pembelajaran dikatakan efektif apabila difokuskan pada kegiatan pembelajaran yang ditujukan untuk mencapai tujuan pembelajaran dalam waktu yang diharapkan (Zheng et al., 2014). Komponen yang diperlukan 
dalam mencapai keberhasilan proses pembelajaran adalah adanya tujuan pembelajaran, bahan pembelajaran, media pembelajaran, media pembelajaran, metode pembelajaran, dan evaluasi pembelajaran (Abdullah, 2017; Nurrita, 2018).

Saat ini mata kuliah yang ditawarkan di STKIP PGRI Sumatera Barat belum sepenuhnya menggunakan materi ajar berbasis pendidikan karakter. Ini dilihat pada mata kuliah reading di program studi pendidikan bahasa Inggris. Materi ajar yang diberikan kepada mahasiswa cenderung berupa teks umum yang berorientasi pada hardskills. Sedangkan dalam pendidikan karakter harus seimbang antara hardskills dan softskills. Selain itu, materi ajar yang diberikan kepada mahasiswa umumnya kumpulan teks yang diambil dari beberapa buku sumber. Hal ini mengakibatkan materi yang diberikan kurang variatif dan menjemukan sehingga mengakibatkan mahasiswa tidak tertarik untuk membaca materi tersebut. Hal ini sejalan dengan penelitian yang dilakukan oleh Sesmiyanti et al (2018) yang menemukan bahwa minat membaca mahasiswa prodi Pendidikan Bahasa Inggris masih kurang.

Materi ajar atau bahan ajar dirancang, disusun, dan dikembangkan untuk membantu baik peserta didik maupun pendidik dalam proses pembelajaran agar dapat membangun suasana pembelajaran yang lebih hidup, menarik, dan inovatif (Sesmiyanti et al., 2018). Bahan ajar ini berperan sebagai pencerminan sudut pandang yang tajam dan inovatif mengenai pengajaran serta aplikasinya, penyajian sumber pokok masalah yang tersusun rapi dan bertahap sesuai dengan kebutuhan dan minat peserta didik yang disajikan dengan metode - metode yang dapat memotivasi peserta didik, dan penunjang bagi latihan dan tugas praktis sebagai bahan evaluasi yang tepat guna (Iskandarwassid dan Sunendar dalam Bahtiar, 2015). Dengan kata lain, selain pendidik, materi ajar atau bahan ajar mempunyai peranan yang sangat penting dalam proses pembelajaran demi mencapai tujuan dan hasil pembelajaran yang diinginkan.

Oleh karena itu, dalam hal ini dosen sebagai pendidik dituntut untuk mampu berkreasi dan berinovasi untuk menghasilkan sebuah bahan ajar yang meliputi semua aspek peranan bahan ajar seperti yang dijelaskan diatas. Salah satu contoh kreasi dan inovasi yang dilakukan oleh pendidik dalam menghasilkan sebuah materi ajar yaitu dengan menggunakan multimodality (multimodal) yaitu kombinasi dari mode yang berbeda dalam komunikasi (Van Leeuwen, dalam Hermawan, 2013). Multimodality adalah pelibatan dua atau lebih model komunikasi dalam pembelajaran bahasa (Winiharti \& Herlina, 2016). Selain itu, multimodal adalah perspektif teoritis yang menegaskan makna komunikatif dilakukan melalui penggunaan dari beberapa mode, mulai di tulisan, ucapan, gambar, suara, gesture, tipografi, gambar bergerak, dan sebagainya (Callow \& Callow, 2013; Jewitt et al., 2016). Dewasa ini, dominasi penggunaan multimodality mulai meningkat. Tidak hanya dalam halaman majalah atau media seni namun juga dalam proses belajar dan pembelajaran. Dalam dunia pendidikan, multimodal sudah banyak digunakan baik dalam penyusunan materi ajar maupun buku teks. Sehingga pembelajaran tidak hanya terbatas pada satu bentuk mode saja, akan tetapi dapat berupa gabungan dari beberapa modes. Lebih lanjut, pembelajaran multimodal memberikan konsep baru dalam berpikir dan memahami materi yang ditampilkan. Jenis teks digital yang dapat diakses dari perspektif kebahasaan lebih banyak melibatkan ditemukan ketimbang teks tradisional yang berbasis tulisan dan bacaan (Walsh, 2011). Contohnya, teks dalam sebuah blog yang didesain, dihasilkan, dan ditulis dalam fungsi visual. Blog dapat melibakan teks tertulis, gambar, grafik, video, dan suara, dapat dibaca, didengar, dan direspon oleh pembaca dengan teks, gambar, video atau suara.

Penelitian yang relevan dengan penelitian ini adalah penelitian yang dilakukan oleh Lestariningsih \& Suardiman (2017) yang berjudul Pengembangan Bahan Ajar Tematik-Integratif Berbasis Kearifan Lokal Untuk Meningkatkan Karakter Peduli Dan Tanggung Jawab. Penelitian ini bertujuan menghasilkan bahan ajar tematik integratif berbasiskearifan lokal yang layak untuk meningkatkan karakter peduli dan tanggung jawab siswa dan menguji keefektifan bahan ajar tersebut pada tingkat Sekolah Dasar (SD). Hasil penelitian menunjukkan bahwa bahan ajar yang dikembangkan ini dapat meningkatkan karakter peduli dan tanggung jawab siswa. Penelitian 
lainnya adalah penelitian yang dilakukan oleh Padmadewi (2015) yang berjudul Pengembangan Perangkat Pembelajaran BerbasisPendidikan Karakter Untuk Mata Kuliah Strategi Pembelajaran Bahasa Jurusan Pendidikan Bahasa Jepang Di Universitas Pendidikan Ganesha Singaraja. Penelitian ini bertujuan untuk mengembangkan perangkat pembelajaran yang berbasis Pendidikan Karakter untuk Mata Kuliah Strategi Pembelajaran Bahasa di Jurusan Pendidikan Bahasa Jepang Universitas Ganesha. Hasil penelitian menghasilkan pengembangan 3 produk utama yaitu silabus, SAP dan RPP, instrument asesmen serta perangkat tambahan untuk memperkuat implementasi pendidikan karakter.

Selain itu, penelitian yang berkaitan dengan multimodality dilakukan oleh Yulian \& Yuniarti (2019) yang berjudul Pengembangan Bahan Ajar Business English Berbasiskan Pendekatan Multimodality Dan Authentic Materials menghasilkan sebuah pengembangan bahan ajar yang digunakan pada mata kuliah Business English dengan pendekatan multimodality dan authentic materials. Berdasarkan penelitian relevan tersebut, belum ada penelitian yang menggabungkan penggunaan multimodality dan pendidikan karakter, untuk mengisi gap tersebut, peneliti mengembangkan buku ajar yang berbasis pendidikan karakter dengan menggunakan multimodality yang digunakan pada mata kuliah Basic Reading.

Penelitian ini mengembangkan buku ajar Reading menggunakan multimodality yang berorientasi pada pendidikan karakter. Penelitian ini bertujuan untuk mengembangkan buku ajar berbasis pendidikan karakter menggunakan multimodality pada mata kuliah reading Prodi Pendidikan Bahasa Inggris STKIP PGRI Sumatera Barat. Penelitian ini penting manfaatnya bagi peserta didik yaitu dapat memotivasi peserta didik untuk membaca dan menghasilkan peserta didik yang mempunyai kemampuan hardskills dan softskills yang seimbang. Selain itu, manfaat penelitian ini juga dapat dirasakan oleh pendidik yaitu pendidik dapat mengintegrasikan antara hardskills dan softskills dalam proses pembelajaran.

\section{METODE}

Jenis penelitian yang dilaksanakan adalah penelitian Research and Development (RnD). Penelitian dan pengembangan adalah suatu proses atau langkah-langkah untuk mengembangkan suatu produk baru atau menyempurnakan produk yang telah ada yang dapat dipertanggungjawabkan (Setyosari, 2016). Penelitian dan pengembangan ini menghasilkan sebuah produk yang dapat langsung diaplikasikan.

Model pengembangan yang digunakan dalam penelitian ini adalah model pengembangan ADDIE yaitu Analysis, Development, Design, Implementation, and Evaluation. Model pengembangan ini dipilih dengan pertimbangan bahwa model tersebut cocok untuk mengembangkan buku ajar yang tepat sasaran, efektif, dan dinamis serta sesuai dengan kebutuhan mahasiswa dan capaian pembelajaran di perguruan tinggi. Subjek dalam penelitian ini adalah mahasiswa dan dosen prodi Pendidikan Bahasa Inggris STKIP PGRI Sumatera Barat yang telah mengikuti mata kuliah Basic Reading. Secara visual tahapan ADDIE Model dapat dilihat pada gambar 1 ini;

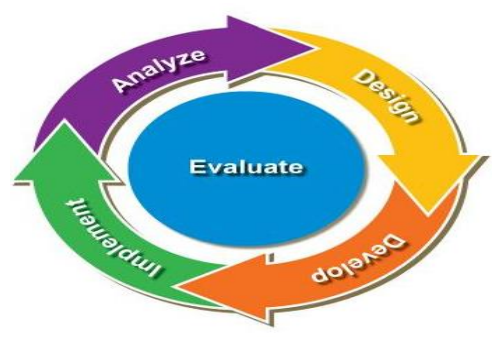

\section{Gambar 1. Tahapan Model ADDIE (Kurt, 2017)}

Adapun kegiatan yang dilakukan pada tahap - tahapnya diuraikan sebagai berikut: 1. Tahap Analisa (Analysis) 
Pada tahap awal atau tahap analisa ini dilakukan studi pendahuluan untuk mengidentifikasi masalah yang dihadapi dalam proses pembelajaran reading di prodi pendidikan Bahasa Inggris STKIP PGRI Sumatera Barat. Studi pendahuluan dilakukan dengan dua cara yaitu dengan studi literatur untuk memperoleh teori tentang pentingnya pendidikan karakter. Observasi, wawancara, dan analisa kebutuhan peserta didik dan pendidik mengenai bahan ajar reading berbasis pendidikan karakter dilakukan untuk memperoleh data faktual di lapangan.

2. Tahap Perancangan (Design)

Setelah data awal diperoleh, maka tahap selanjutnya adalah mendesain buku ajar yang berbasis pendidikan karakter dan menggunakan multimodality. Data dan informasi yang diperoleh dijadikan sebagai bahan pertimbangan untuk merancang bahan ajar yang sesuai dengan potensi dan kebutuhan peserta didik berdasarkan dengan mengklarifikasi bahan ajar yang didesain sehingga buku ajar yang dihasilkan dapat mencapai tujuan pembelajaran yang diharapkan. Bahan ajar berbasis pendidikan karakter yang akan digunakan dirancang menggunakan multimodality.

3. Tahap Pengembangan (Develop)

Setelah mendesain bahan ajar dengan menggunakan multimodality, bahan ajar tersebut dikembangkan sesuai dengan pendidikan karakter yang dibutuhkan baik oleh peserta didik maupun bagi pendidik untuk meningkatkan kemampuan hardskills dan softskills mahasiswa. Desain bahan ajar yang menggunakan multimodality dan berbasis pendidikan karakter ini, selanjutnya akan divalidasi oleh tim ahli, yaitu pakar pendidikan dan dosen sebelum diimplementasikan kepada peserta didik.

4. Tahap Implementasi (Implementation)

Pada tahap ini, semua yang telah dikembangkan, diinstal dan dikembangkan sedemikian rupa sesuai dengan peran atau fungsinya agar bisa diimplementasikan. Setelah produk siap, maka dapat diuji cobakan melalui kelompok kecil kemudian dievaluasi dan direvisi. Kemudian uji coba dapat dilakukan pada kelompok besar kemudian dievaluasi kembali dan direvisi sehingga menghasilkan produk akhir yang siap didiseminasikan. Pada fase ini, kegiatan yang akan dilakukan adalah menggunakan buku ajar reading berbasis pendidikan karakter pada satu sesi mata kuliah Basic Reading program studi pendidikan bahasa Inggris STKIP PGRI Sumatera Barat. Penggunaan buku ajar berbasis pendidikan karakter ini merupakan tahap uji coba sebelum menghasilkan produk akhir yang akan dipatenkan.

5. Tahap Evaluasi (Evaluation)

Tahap evaluasi merupakan suatu proses untuk melihat materi ajar yang dikembangkan sesuai dengan harapan awal atau tidak. Kegiatan yang dilakukan pada fase terakhir ini adalah evaluasi terhadap buku ajar reading berbasis pendidikan karakter. Pada tahap evaluasi ini, tim peneliti akan mengevaluasi hasil belajar mahasiswa yang telah menggunakan buku ajar reading yang dikembangkan dengan multimodality dan berbasis pendidikan karakter. Selain itu, peneliti juga akan menganalisa respon dosen dan mahasiswa terhadap buku ajar reading tersebut. Tanggapan positif dari mahasiswa maupun dosen merupakan dampak dari keefektifan buku ajar.

Teknik pengumpulan data pada penelitian ini menggunakan analisa dokumen, kuisioner, wawancara, dan validasi tim ahli (expert judgment). Analisa dokumen dilakukan untuk mengetahui pendidikan karakter yang terdapat pada buku ajar yang digunakan pada mata kuliah Basic Reading. Wawancara dilakukan untuk mengetahui proses pembelajaran pada mata kuliah Basic Reading. Kuisioner digunakan untuk mengetahui kebutuhan pendidikan karakter mahasiswa dan dosen pada mata kuliah Basic Reading. Selain itu,hasil analisa dokumen, wawancara, dan kuisioner digunakan sebagai bahan pertimbangan dalam mengembangkan buku ajar yang berorientasi pada pendidikan karakter dengan menggunakan multimodality yang dibutuhkan pada mata kuliah Basic Reading. Lembar validasi digunakan untuk menilai kelayakan buku ajar yang akan dilakukan oleh ahli materi, ahli bahasa, dan praktisi, yaitu dosen. Saran dan masukan dari tim ahli ini akan digunakan sebagai dasar dalam memperbaiki produk buku ajar ini sehingga diperoleh buku ajar yang layak digunakan 
dalam proses pembelajaran. Analisa data yang digunakan yaitu analisis deskriptif kualitatif untuk data dokumen,wawancara, dan angket; dan deskriptif kuantitatif untuk validsi dari tim ahli.

\section{HASIL PENELITIAN DAN PEMBAHASAN \\ Analyze}

Studi pendahuluan dilakukan untuk memperoleh informasi dan data tentang proses perkuliahan dan buku ajar yang digunakan pada mata kuliah Basic Reading. Hasil analisa dokumen menjelaskan bahwa buku ajar yang digunakan pada mata kuliah Basic Reading belum memiliki multimodality dan berbasis pendidikan karakter. Berdasarkan hasil indikator dari multimodality yaitu; gambar, variasi tulisan, grafik dan tabel serta ujaran (Callow, 2013;Walsh 2012), ditemukan bahwa pada indikator gambar,terdapat beberapa gambar pada buku ajar yang digunakan akan tetapi gambar tersebut tidak mempunyai warna. Gambar tersebut berwarna hitam dan putih yang mana gambar tersebut tidak terlalu menarik. Akan tetapi, gambar tersebut tidak terdapat di dalam teks. Gambar tersebut diletakkan pada awal bab dan digunakan sebagai brainstorming atau untuk mengaktifkan pengetahuan awal mahasiswa.

Hasil analisa pada variasi tulisan menunjukkan bahwa buku ajar reading yang digunakan ditemukan bahwa buku ajar reading yang digunakan mempunyi variasi tulisan seperti tulisan yang dimiringkan dan tulisan yang digarisbawahi, akan tetapi tidak ada variasi tulisan yang dihitamkan dan tidak ada tulisan yang ukuran huruf dan gaya yang berbeda di dalam buku tersebut. Tulisan yang dimiringkan dan tulisan yang digarisbawahi digunakan untuk menguatkan isi dari materi yang dijelaskan. Sedangkan hasil dari dokumen ceklist, pada buku ajar yang digunakan ditemukan bahwa buku ajar yang digunakan mempunyai tabel tidak mempunyai grafik. Ada tiga tabel yang ditemukan di dalam buku ajar yang digunakan dan tabel tersebut tidak mempunyai warna. Hasil dokumen analisis menunjukkan bahwa tidak ada ujaran yang ditemukan di dalam buku ajar reading yang digunakan.

Hasil wawancara tentang kebutuhan buku ajar yang diperlukan pada perkuliahan Basic Reading menunjukkan bahwa, baik mahasiswa maupun dosen membutuhkan sebuah buku ajar yang menarik minat dan meningkatkan motivasi membaca. Sehingga, penggunaan multimodality sangat diperlukan dalam mengembangkan buku ajar Basic Reading ini. Hal ini sejalan dengan penelitian yang dilakukan oleh Yulian dan Yuniarti (2019) dimana mahasiswa lebih tertarik dan termotivasi untuk membaca teks berbahasa Inggris yang menggunakan multimodal.

Temuan dari dokumen ceklist menunjukkan terdapat delapan karakter yang dimiliki oleh buku ajar pada mata kuliah reading yang digunakan oleh program studi Pendidikan Bahasa Inggris STKIP PGRI Sumatera Barat. Delapan karakter tersebut adalah; toleransi, disiplin, kreatif, cinta tanah air, kreatif, bekerja keras, peduli sosial dan tanggung jawab. Akan tetapi, karakter yang ditemukan dalam buku ajar reading yang digunakan hanya dalam bentuk kalimat sederhana yang belum menunjukkan pengajaran dan pengimplementasian pendidikan karakter yang sesuai dengan tujuan Kurikulum Pendidikan Nasional tahun 2010. Karakter - karakter yang tidak ditemukan dalam buku ajar tersebut adalah beragama, jujur, mandiri, demokratis, rasa ingin tahu, semagat kebangsaan, menghargai prestasi, cinta damai, gemar membaca dan peduli lingkungan. Untuk itu, perlu dilakukan pengembangan buku ajar yang berdasarkan pendidikan karakter sehingga dapat menghasilkan generasi penerus bangsa yang sesuai dengan tujuan pendidikan Nasional.

Hasil wawancara menunjukkan bahwa mahasiswa dan dosen membutuhkan pendidikan karakter dalam pengembangan buku ajar Basic Reading. Analisa kebutuhan pendidikan karakter yang diperlukan oleh dosen adalah; nilai pendidikan karakter yang diperlukan adalah nilai kemanusiaan yang dimaksudkan diterapkan atau diimplementasikan kepada sikap dan perilaku dalam menjalankan tugas yang sesuai dengan agama, moral, dan etika. Sedangkan sikap yang dimaksudkan dalam kepekaan sosial merupakan sikap kepedulian dan kerjasama dalam masyarakat dan lingkungan. Sikap yang berhubungan dengan kehidupan bermasyarakat dan bernegara ini menunjukkan sikap taat hukum, disiplin dan bertanggung jawab atas pekerjaan di bidang 
keahliannya secara mandiri. Selain itu, karakter yang berhubungan dengan kemampuan untuk mengatur diri sendiri berhubungan dengan disiplin, tanggung jawab, komitmen, dan profesional. Informan juga mengungkapkan bahwa karakter jujur, empati, dan kemampuan untuk menghargai orang lain juga diperlukan dalam proses pembelajaran mata kuliah Basic Reading yang diintegrasikan pada buku ajar.

Sedangkan nilai pendidikan karakter yang diperlukan oleh mahasiswa tidak jauh berbeda dengan informan dosen yang menyatakan bahwa aspek yang harus ada berhubungan dengan nilai kemanusiaan, kepekaan sosial, dan kehidupan bermasyarakat dan bernegara. Dalam mengatur diri sendiri, informan mengungkapkan karakter yang diperlukan adalah karakter yang berhubungan dengan diri sendiri dan orang lain. Karakter yang berhubungan dengan diri sendiri ini diturunkan menjadi karakter seperti jujur, disiplin, dan tanggung jawab. Sedangkan karakter berupa kemampuan untuk berhubungan dengan orang lain yaitu kemampuan untuk bekerja sama dengan teman, bersahabat/komunikatif dan saling menghargai dalam menerima pendapat orang lain. Karakter ini perlu untuk dimiliki oleh mahasiswa yang nantinya bermanfaat pada dunia nyata dan kerja. Hal ini sesuai dengan karakter yang dikembangkan dalam pendidikan karakter berdasarkan Kemendiknas (Normawati, 2015). Karakter-karakter yang dibutuhkan oleh mahasiswa diintegrasikan dalam proses belajar mengajar dan perlu untuk dikembangkan dalam buku ajar Basic Reading ini adalah karakter yang dapat meningkatkan kinerja mahasiswa untuk ke depannya.

\section{Design}

Hasil studi pendahuluan dijadikan sebagai salah satu pedoman dalam penyusunan draft produk buku ajar Basic Reading. Dalam menyusun desain produk buku ajar ini, terdapat beberapa hal yang harus dilakukan yakni menentukan capaian pembelajaran mata kuliah yang disesuaikan dengan Kerangka Kualifkasi Nasional Indonesia (KKNI). Dalam penelitian ini, capaian pembelajaran yang difokuskan menjadi empat bagian yaitu, capaian pembelajaran sikap, keterampilan umum, keterampilan khusus, dan pengetahuan. Pada aspek sikap, capaian pembelajaran mata kuliah disesuaikan dengan hasil analisa kebutuhan mahasiswa yang dilakukan sebelumnya, yaitu kejujuran, tanggung jawab, disiplin, dan kerjasama.Sedangkan untuk aspek keterampilan umum, keterampilan khusus, dan pengetahuan, capaian pembelajaran yang dibutuhkan adalah memahami keterampilan dasar membaca seperti skimming, scanning, previewing, predicting, dan summarizing. Selain itu, pada buku ajar ini, konten dan isi buku ajar ini membahas tentang memahami topik, ide pokok, dan memahami context clues.

Materi ajar dalam buku ini disajikan dalam tiga bagian yaitu pendahuluan, isi, dan latihan. Bagian pertama, pendahuluan (introduction) menyajikan tentang informasi awal materi yang akan dipelajari, relevansinya pada dunia nyata atau dunia kerja, dan capaian pembelajaran yang akan tercapai pada bab tersebut. Bagian kedua yaitu isi (content) menyajikan materi yang akan dipelajari pada bab tersebut, sedangkan bagian terakhir yaitu latihan ( exercise), menyajikan latihan - latihan yang dapat mengembangkan dan meningkatkan keterampilan membaca mahasiswa yang disesuaikan dengan materi yang dipelajari.

\section{Development}

Desain awal produk yang telah ditentukan sebelumnya menjadi pedoman bagi peneliti dalam mengembangkan dan menyusun buku ajar Basic Reading menggunakan multimodality dan berorientasi pada pendidikan karakter. Dalam mengembangkan dan menyusun capaian pembelajaran, peneliti menghubungkannya dengan karakter apa yang dapat dicapai oleh peserta didik setelah mengikuti perkuliahan tersebut. Selain itu, berdasarkan analisa kebutuhan peserta didik, peneliti juga mengembangkan buku ajar ini berdasarkan konten atau isi, peneliti menyisipkan nilai-nilai pendidikan karakter dengan mencari contoh-contoh yang berisi tentang pendidikan karakter. Selain itu, pada bagian latihan, peneliti juga menyisipkan nilai pendidikan karakter seperti, berkelompok dalam menyelesaikan tugas atau latihan yang diberikan, memberikan latihan yang 
mengandung nilai karakter seperti cinta lingkungan, dan melatih nilai kejujuran dengan meminta peserta didik untuk menilai sendiri tugas atau latihan yang telah dikerjakan.

Berikut merupakan desain dan pengembangan buku ajar Basic Reading berdasarkan pendahuluan, isi, dan latihan.

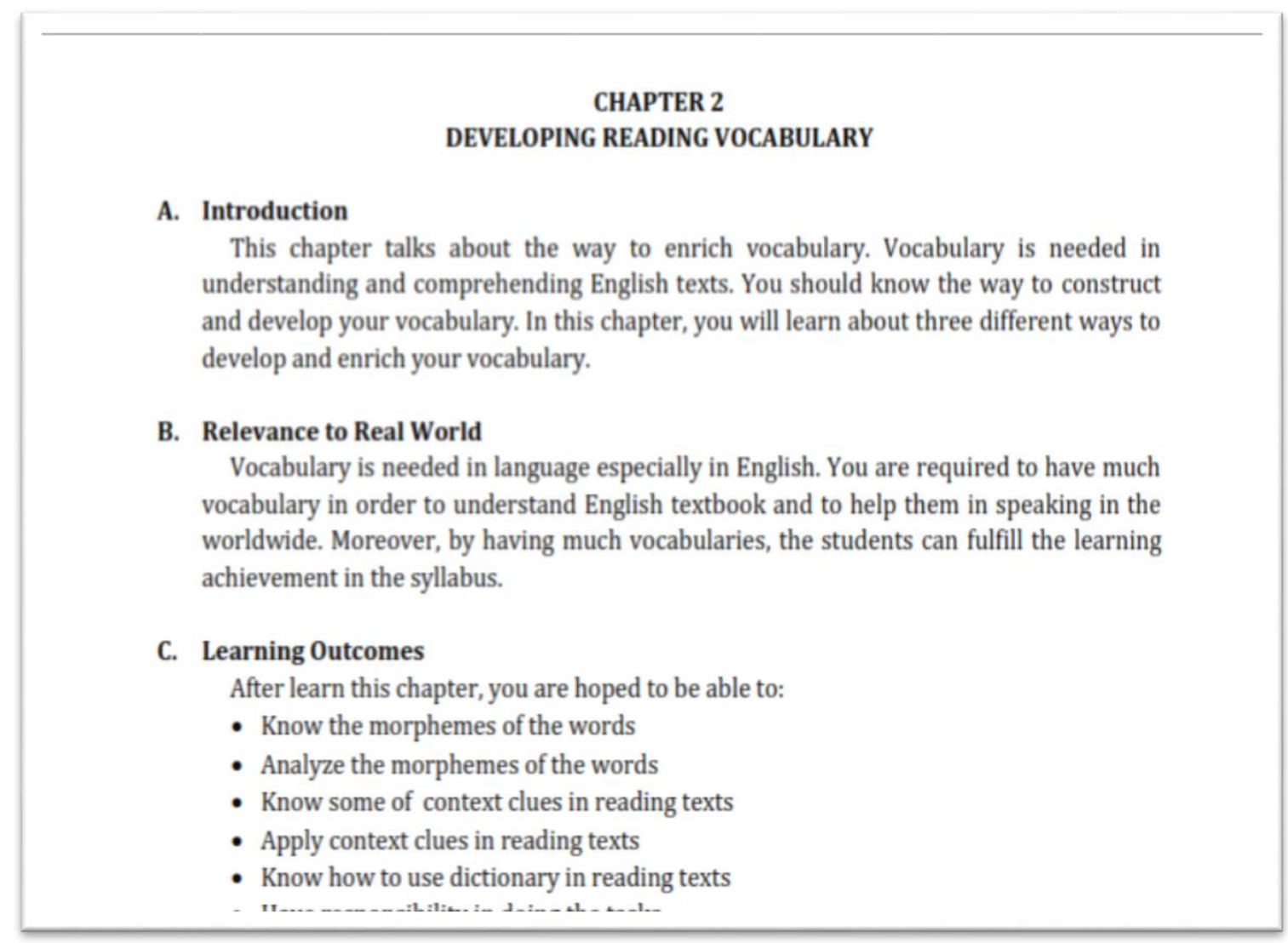

\section{Gambar 2. Bagian Pendahuluan Buku Ajar Basic Reading}

Pada bagian pendahuluan, peneliti mengembangkan bagian tersebut menjadi tiga bagian yaitu, pendahuluan, relevansi pada dunia nyata, dan capaian pembelajaran yang akan dicapai pada bab tersebut. Gambar diatas menunjukkan, pada bagian pendahuluan, peneliti mendeskripsikan tentang materi yang akan dipelajari pada bab tersebut, sedangkan pada bagian relevansi pada dunia nyata, peneliti memberikan alasan kenapa materi pada bab tersebut dipelajari dan manfaatnya pada kehidupan sehari - hari. Pada bagian capaian pembelajaran, peneliti menyisipkan nilai karakter yang dapat dicapai oleh peserta didik setelah mempelajari materi pada buku ajar Basic Reading ini, sehingga peserta didik dapat menguasai hardskills dan softskills secara bersamaan. 
2. Description.

This particular method for adding information is certain to get the reader directly involved as it appeals to the five senses. When one uses description, it is usually to answer questions for the reader such as "What did it sound like?" "What did it smell like?' In describing, the writer works to develop word pictures, to image the scene for the reader whether it be an object, person, or event.

c. Distinguishing Main Ideas from Supporting Details

What's a Main Idea?

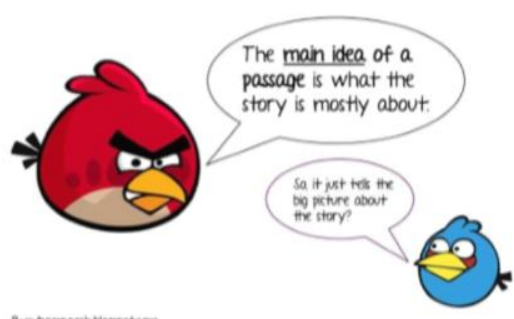

Text usually contains a small number of main ideas. Each main idea may be supported by examples, reasons, further information and other supporting details. To

- Example or explanation

Sometimes when a reader finds a new word, an example might be found nearby that helps to explain its meaning. Words like including, such as, and for example, point out example clues.

Examples:

b. Piscatorial creatures, such as flounder, salmon, and trout, live in the coldest parts of the ocean.

Piscatorial obviously refers to fish.

c. Celestial bodies, including the sun, moon, and stars, have fascinated man through the centuries.

Celestial objects are those in the sky or heavens.

d. In the course of man's evolution, certain organs have atrophied. The appendix, for example, has wasted away from disuse.

Atrophied means wasted away.

- General Knowlegde Context

In general knowledge contexts, it expects the reader to derive the meaning from the reader's own background or experience using common sense or logic. The author uses several words that gives clues to the word's meaning

\section{Gambar 3. Bagian Isi Buku Ajar Basic Reading}

Pada bagian isi, peneliti mengembangkan aspek pendidikan karakter dan multimodality. Berdasarkan studi pendahuluan dan analisa kebutuhan peserta didik dan pendidik, diketahui bahwa buku ajar yang dibutuhkan adalah buku ajar yang mempunyai unsur gambar dan berwarna. Pada gambar diatas (gambar pertama dan kedua), peneliti mendesain dan mengembangkan buku ajar dengan menggunakan aspek multimodality yaitu gambar dan warna huruf, sedangkan pada gambar berikutnya, peneliti memuat unsur nilai karakter pada materi ajar yang diberikan yang nampak pada contoh - contoh yang diberikan.

Nilai karakter pada buku ajar ini lebih ditonjolkan pada bagian latihan dimana peserta didik diminta untuk mengerjakan latihan secara berkelompok dan berdiskusi untuk menerapkan nilai kerjasama dan membangun rasa saling menghargai. Selain itu, latihan -latihan yang diberikan juga ditujukan untuk mengamalkan nilai tanggung jawab dan disiplin dimana peserta didik diminta untuk menyelesaikan latihan-latihan yang diberikan secara tepat waktu. Sedangkan unsur multimodality yang digunakan pada latihan dalam buku ajar ini lebih mengutamakan penggunaan gambar, warna, dan variasi tulisan. Hal ini dapat dilihat pada gambar berikut ini;

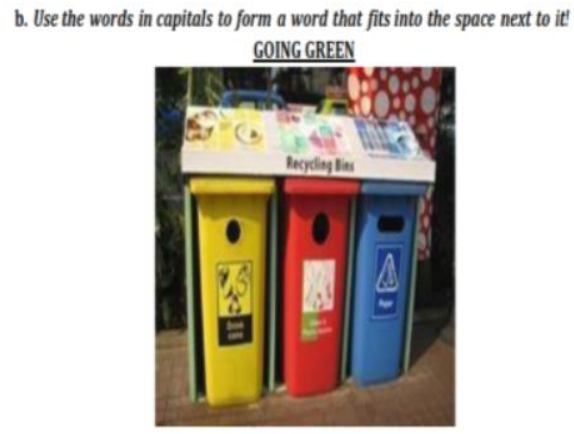

$$
\begin{aligned}
& \text { There is an ___ (ARGUE) that ___ (RECYCLE) may have some } \\
& \text { unforeseen negative effects. of course, it would be major ___ (ACHIEVE) if } \\
& \text { we were able to increase ___ (AWARE) to the threat of the environment } \\
& \text { caused by ___ (POLLUTE) and the ___ (BURN) of fossil fuels. } \\
& \text { However, if the public's only (INVOLVE) ___ in ecological issues is } \\
& \text { taking their newspapers and bottles to a recycling point, we may only be creating the } \\
& \text { (APPEAR) of } \\
& \text { (IMPROVE). }
\end{aligned}
$$

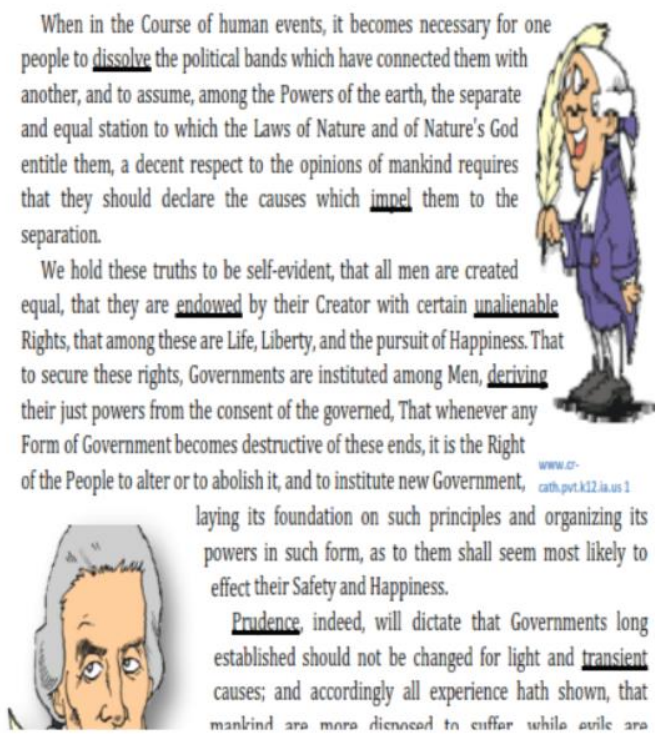

When in the Course of human events, it becomes necessary for one people to dissolve the political bands which have connected them with another, and to assume, among the Powers of the earth, the separate and equal station to which the Laws of Nature and of Nature's God entitle them, a decent respect to the opinions of mankind requires that they should declare the causes which imnel them to the separation.

We hold these truths to be self-evident, that all men are created equal, that they are endowed by their Creator with certain unalienabl Rights, that among these are Life, Liberty, and the pursuit of Happiness. That to secure these rights, Governments are instituted among Men, deriving their just powers from the consent of the governed, That whenever any Form of Government becomes destructive of these ends, it is the Right of the People to alter or to abolish it, and to institute new Government, athon laying its foundation on such principles and organizing its powers in such form, as to them shall seem most likely to effect their Safety and Happiness.

Prudence, indeed, will dictate that Governments long established should not be changed for light and transient causes; and accordingly all experience hath shown, that mankind are mnre dienneed th euffer while ovile are

\section{Gambar 4. Bagian Latihan Buku Ajar Basic Reading}




\section{Validasi Produk}

Draft awal buku ajar Basic Reading yang telah dikembangkan dan dihasilkan selanjutnya dilakukan uji validitas untuk mengukur kelayakan produk yang telah dikembangkan. Penilaian kelayakan produk ini dilakukan dengan penilaian dari tim ahli yang terdiri dari ahli pendidikan dan praktisi yaitu dosen, dosen yang menjadi penilai buku ini adalah dosen yang mengajar mata kuliah Basic Reading. Saran dan masukan yang diberikan oleh tim ahli akan dijadikan sebagai bahan perbaikan dan revisi untuk menyempurnakan buku ajar Basic Reading yang telah dihasilkan.Aspek yang dinilai untuk menguji kelayakan produk ini meliputi: 1) kelayakan isi 2) kelayakan penyajian 3) kelayakan bahasa 4) penilaian buku ajar reading menggunakan multimodality yang berorientasi pada pendidikan karakter.

Hasil uji kelayakan produk buku ajar Basic Reading yang dilihat dari segi praktikalitas dan validitas menunjukkan bahwa buku ajar ini telah layak digunakan. Hal ini dapat dilihat pada diagram berikut ini;

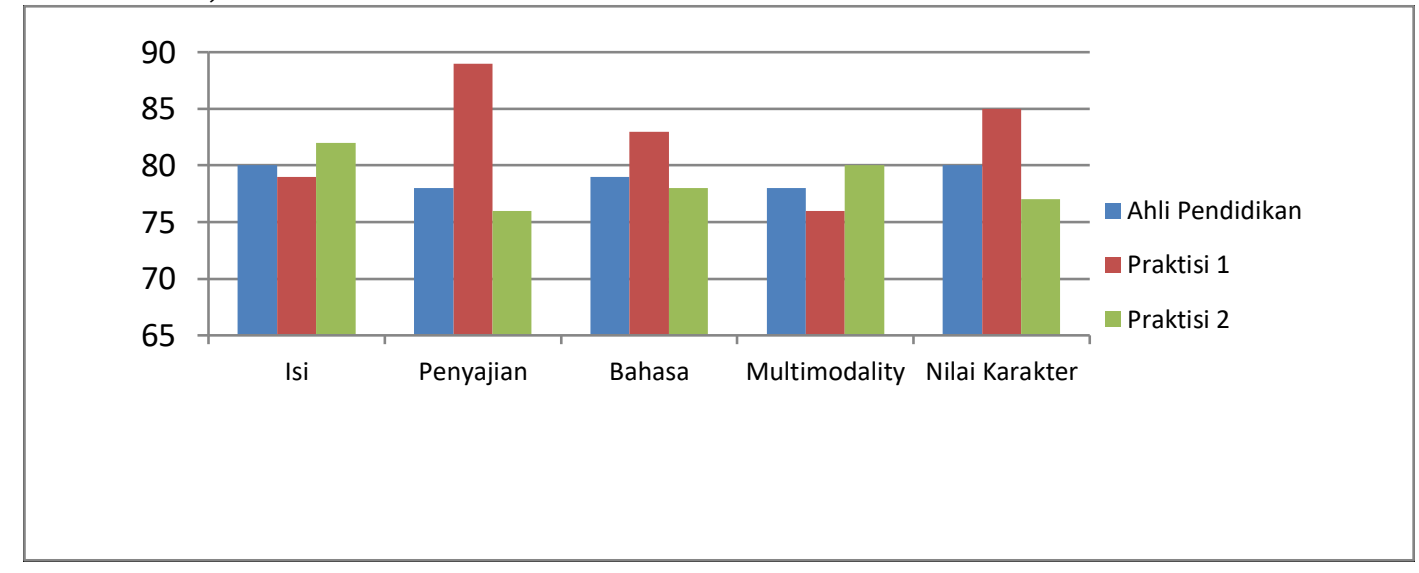

\section{Gambar 5. Hasil Uji Kelayakan Buku Ajar}

Berdasarkan grafik diatas, dapat dilihat bahwa pada komponen kelayakan isi, yang terdiri dari kesesuaian materi dengan capaian pembelajaran, keakuratan materi, pendukung materi pembelajaran, kemuthakiran materi, diperoleh hasil yaitu untuk ahli pendidikan didapat 80\%, dan praktisi, dosen pertama didapat 79\% sedangkan dosen kedua diperoleh 82\%dengan hasil yang dikategorikan pada kriteria valid. Kemudian pada aspek kedua yaitu tentang aspek kelayakan penyajian dengan sub komponen yang terdiri dari teknik penyajian, pendukung penyajian, penyajian dan kelengkapan. Hasil angket diperoleh data sebagai berikut, untuk ahli pendidikan diperoleh hasil sebesar 78\%, praktisi, dengan dosen pertama diperoleh hasil $89 \%$ sedangkan dosen kedua didapat $76 \%$, dengan kriteria valid untuk ketiga validator. Setelah itu untuk komponen ketiga yaitu penilaian bahasa yang mencakup lugas, komunikatif, dialogis dan interaktif, kesesuaian dengan perkembangan peserta didik, keruntutan dan keterpaduan alur pikir, penggunaan atau ikon. Hasil angket pada komponen ini menunjukkan hasil dari ahli pendidikan menunjukkan angka 79\% dengan kriteria valid, sedangkan praktisi yaitu dosen pertama diperoleh 83\%dengan kriteria valid dan dosen kedua diperoleh $78 \%$ dengan kriteria valid.

Selain itu indikator validitas buku ajar terdiri dari sumber materi yang meliputi kajian multimodality dan pendidikan karakter dengan mengembangkan buku ajar yang dapat meningkatkan kemampuan hard skill dan soft skill peserta didik, pengembangan buku ajar basic reading dengan menggunakan multimodality mengacu kepada kemampuan hard skill peserta didik sedangkan untuk meningkatkan kemampuan peserta didik tentang soft skill, dalam mengembangkan buku ajar reading, maka diterapkan pembelajaran yang mengacu pada 18 nilai karakter yang perlu ditanamkan yang bersumber dari Agama, Pancasila, Budaya, dan Tujuan Pendidikan Nasional. Dari hasil angket diperoleh data untuk multimodality pada ahli pendidikan sebesar $78 \%$ dengan kriteria valid dan praktisi, dosen pertama yaitu $76 \%$ dengan kriteria valid dan dosen kedua sebesar 80\% dengan kriteria valid. Sedangkan validitas komponen pendidikan karakter 
didapatkan hasil angket pada ahli pendidikan sebesar 80\%, praktisi dengan dosen pertama sebesar 85\% sedangkan dosen kedua sebesar 77\% dengan hasil yang dikategorikan pada kriteria valid. Hasil ini berdasarkan uji SPSS dan validasi dengan ahli dan praktisi.

Hasil dari uji validitas untuk melihat kelayakan awal buku ajar Basic Reading ini dapat dilihat dari hasil rata-rata penilaian dari ahli pendidikan dan praktisi. Hal ini dapat dilihat pada diagram berikut ini:

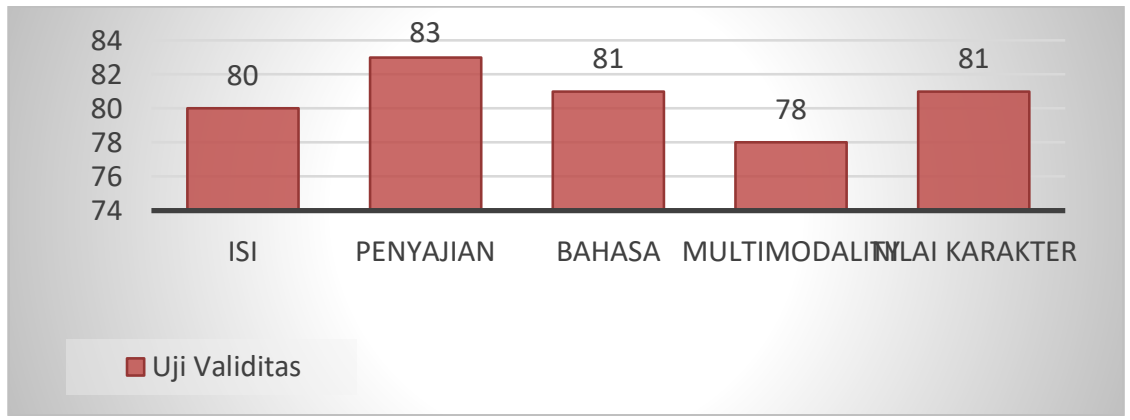

Gambar 6. Hasil Uji Validasi Buku Ajar

Berdasarkan gambar diatas dapat dilihat bahwa rata-rata kelayakan isi memperoleh hasil 80\% dengan kriteria valid, sedangkan rata-rata kelayakan penyajian diperoleh hasil sebesar 83\% dengan kriteria valid, untuk kelayakan bahasa diperoleh hasil rata-rata sebesar $81 \%$, sedangkan aspek multimodality memperoleh rata - rata sebesar $78 \%$ dan nilai karakter dengan rata-rata sebesar $81 \%$. Hasil keseluruhan validasi oleh ahli pendidikan dan praktisi diperoleh persentase rata-rata sebesar 81\% sehingga buku ajar Basic Reading ini dapat dikatakan layak untuk diujicobakan dan digunakan dalam proses perkuliahan mata kuliah Basic Reading.

Adapun saran dan masukan yang diberikan oleh ahli pendidikan dan praktisi dalam upaya perbaikan dan penyempurnaan buku ajar ini, diantaranya adalah perlunya penambahan materi atau konten yang mengandung nilai karakter sehingga nilai karakter yang tercakup dalam buku ajar ini tidak hanya terdapat pada latihan akan tetapi juga terdapat pada materi ajar. Selain itu, aspek multimodality, terutama gambar, belum terdapat pada setiap bab yang ada pada buku ajar ini sehingga perlu untuk ditambahkan. Berdasarkan saran yang diberikan oleh ahli pendidikan dan praktisi tersebut maka, tim peneliti menambahkan materi yang memiliki pendidikan karakter yaitu teks naratif yang mempunyai nilai tanggung jawab pada bab Finding Main Ideas. Selain itu, tim peneliti juga mendesain dan menambahkan beberapa gambar sehingga setiap bab pada buku ajar Basic Reading ini memiliki gambar.

\section{Implementation}

Setelah buku ajar dinyatakan layak untuk digunakan, tim peneliti melakukan uji coba untuk melihat keefektifan buku ajar tersebut. Implementasi buku Basic Reading dalam mata kuliah Reading dilakukan dalam sembilan pertemuan karena keterbatasan waktu penelitian. Data penelitian dimulai dengan melakukan pretest untuk mengetahui kondisi awal kemampuan mahasiswa dalam membaca sebelum menggunakan buku Basic Reading, kemudian setelah penerapan buku dalam mata kuliah tersebut dilakukan posttest.Posttest dilakukan untuk mengetahui peningkatan hasil dari pemahaman mahasiswamenggunakan buku dalam proses pembelajaran. Test yang diberikan berupa test reading comprehension dengan jumlah soal sebanyak 50 soal pilihan ganda dengan waktu 75 menit. Peserta didik diminta untuk menjawab 50 soal dalam waktu 75 menit.

Selain melakukan ujicoba, tim peneliti juga melakukan uji praktikalitas untuk melihat kelayakan penggunaan buku dengan melakukan penyebaran angket pada peserta didik dan praktisi. Ada lima indikator kepraktisan buku ajar Basic Reading yang berorientasi pada pendidikan karakter dan multimodalityyang terdiri dari keefektifan, kreatifitas, efisiensi, interaksi dan menarik. Buku teks terdiri dari beberapa komponen seperti relevansi materi dengan hasil pembelajaran, isi materi, 
lembar kerja dan umpan balik. Relevansi dengan kehidupan nyata atau social berarti bahan yang digunakan dalam buku teks efektif dan efisien untuk digunakan didalam kehidupan sehari-hari. Materi pembelajaran dirancang untuk memenuhi apa yang dibutuhkan peserta didik dan minat peserta didik dalam kehidupan mereka berinteraksi dengan kehidupan sosial.

Buku teks yang bagus juga harus menyatakan hasil pembelajaran yang biasanya dinyatakan di awal setiap bab dalam buku ini. Isi materi terdiri dari materi yang akan dipelajari dalam bab yang relevan dengan materi yang dinyatakan dalam rencana pelajaran semester. Lembar kerja terdiri dari latihan yang diberikan untuk mahasiswa dari setiap materi dalam bab ini. Dalam bagian lembar kerja, peserta didik diminta untuk melakukan beberapa latihan untuk mengukur pemahaman mereka tentang materi sedangkan dalam mendapatkan umpan balik dapat dilihat pada interaksi peserta didik dan dosen dalam proses perkuliahan.Kepraktisan buku ini dilihat berdasarkan efektifitas, kreativitas, efisiensi, interaktivitas dan ketertarikan. Skor untuk efektivitas buku Basic Readingadalah $72 \%$ sedangkan skor untuk kreativitasnya adalah $71 \%$ yang dikategorikan cukup praktis. Efisiensi dan interaktivitas mendapat persentase sebesar $73 \%$ dan $70 \%$ yang juga dikategorikan praktis untuk digunakan. Skor untuk minatnya adalah dalam persentase $73 \%$. Hal ini bisa dilihat pada grafik dibawah ini:

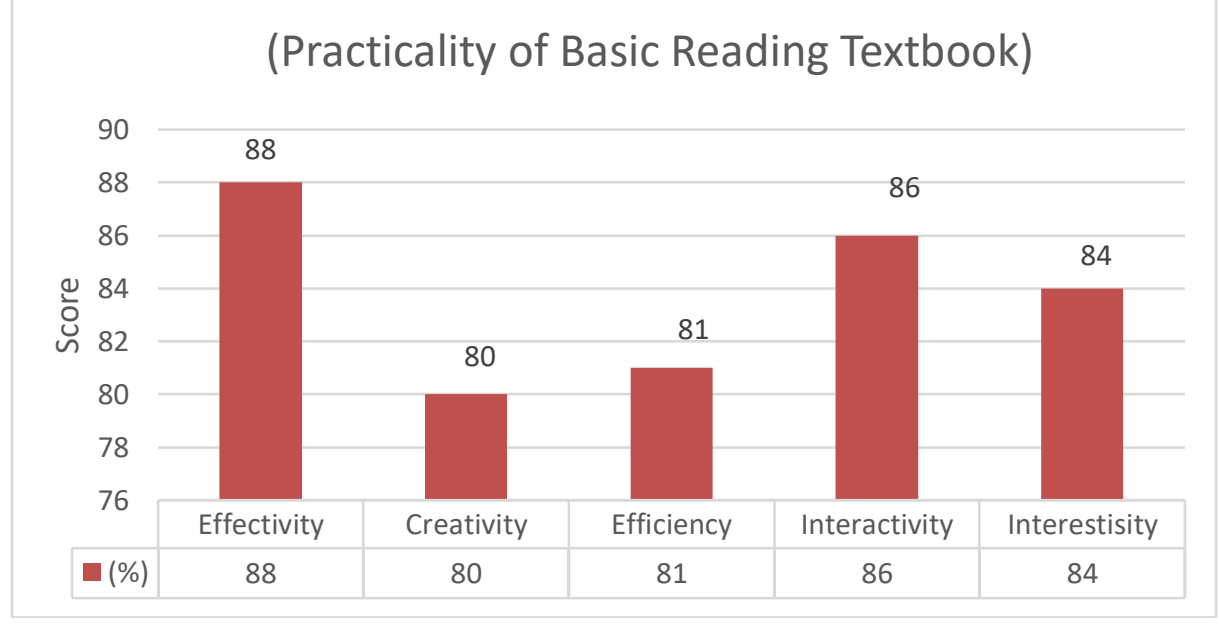

Gambar 7. Hasil Uji Praktikalitas Buku Ajar

Dalam menganalisa hasil pretest dan posttest peserta didik digunakan desain One Group Pretest-Posttest Design, dengan satu kelas yang digunakan untuk mengajar dengan mengunakan buku tersebut dalam proses pembelajaran (Ary et al, 2009). Pre test diberikan pada awal pembelajaran dan postest pada akhir pembelajaran. Kemudian diuji menggunakan T-Test (Paired Samples T-Test) yang digunakan untuk menguji perbedaan rata-rata lebih dari dua sampel, variasi data yang sama, tetapi sampel tidak berhubungan satu sama lain, dan itu dihitung dengan dinormalisasi $\mathrm{N}$-Gain. Skor Gain Normality adalah analisis teknis untuk menentukan tingkat peningkatan hasil pembelajaran sebelum menggunakan buku teks Basic Reading sebelum pembelajaran dan setelah menggunakannya.

Hasil belajar kognitif, dapat dilihat rata-rata hasil belajar kognitif sebelum menggunakan buku Basic Reading dari pretest adalah 63,63 dengan standar deviasi 8,20, standar error adalah 1,58. Kemudian, hasil belajar kognitif setelah menggunakan buku teks bacaan dasar yang telah digunakan oleh mahasiswa pada mata pelajaran yang sama untuk hasil posttest adalah 80,52 dengan standar deviasi 6,12 dan standar error 1,18. Ini berarti kemampuan membaca mahasiswa meningkat setelah menggunakan buku teks Basic Reading. Deskripsi hasil kognitif yang diperoleh dari pretest dan posttest dapat dilihat pada tabel 1 di bawah ini: 
Tabel 1. Deskripsi dari Hasil Cognitive

\begin{tabular}{lcccc}
\hline Jenis Test & Jumlah Peserta & $\begin{array}{l}\text { Rata } \\
\text { Rata }\end{array}$ & $\begin{array}{l}\text { Standard } \\
\text { Error }\end{array}$ & $\begin{array}{l}\text { Standard } \\
\text { Deviation }\end{array}$ \\
\hline Pretest & 27 & 63.63 & 1.58 & 8.20 \\
Posttest & 27 & 80.52 & 1.17 & 6.12 \\
\hline
\end{tabular}

Hasil nilai pretest dan posttest digunakan untuk menentukan efektivitas buku teks Basic Reading dengan menggunakan rumus normalisasi $N$-Gain. Formula ini digunakan untuk menganalisis perbandingan skor pretest dan postest. Hal ini dapat dilihat pada tabel di bawah ini;

Table 2 Hasil Pretest, Posttest, dan N-Gain

\begin{tabular}{llll}
\hline Skor & Minimum & Maximum & $\begin{array}{l}\text { Rata } \\
\text { rata }\end{array}$ \\
\hline Pretest & 50 & 78 & 63.63 \\
Postest & 66 & 94 & 80.52 \\
N-Gain & 0.26 & 0.86 & 0.46 \\
\hline
\end{tabular}

Pada tabel 2, dapat dilihat bahwa skor minimum untuk pretest adalah 50 dan skor maksimum pretest adalah 78 sedangkan skor rata-rata adalah 63,63. Sementara itu, setelah penerapan Buku Basic Reading, skor minimum mahasiswa untuk posttest adalah 66 dan skor maksimum untuk posttest adalah 94 sedangkan skor rata-rata adalah 90,52. Berdasarkan hasil minimum dan skor maksimum pretest dan posttest dari kemampuan membaca mahasiswa, dapat dikatakan bahwa kemampuan membaca mahasiswa meningkat. Selanjutnya, hasil perhitungan Normalisasi $N$-Gain menunjukkan skor rata-rata 0,46 yang dikategorikan sedang.

Dengan meningkatnya nilai posttest dapat dikatakan bahwa penggunaan buku teks bacaan dasar telah efektif untuk diterapkan. Untuk mengevaluasi efektivitas penggunaan buku teks yang telah dilaksanakan, pengujian hipotesis dilakukan dengan menggunakan uji-t (uji-t). Hasil uji-t dapat dilihat pada tabel 3;

Table 3. Hasil T-test

\begin{tabular}{rlllll}
\hline Data & Rerata & $\begin{array}{l}\text { Jumlah } \\
\text { Siswa (N) }\end{array}$ & T-test & P value & Criteria \\
\hline Pre test & 63.63 & 27 & 13.10 & 0.000 & Significant \\
Post test & 80.61 & 27 & & & \\
\hline
\end{tabular}

Berdasarkan perhitungan diperoleh $\mathrm{t}=(\mathbf{1 3 , 1 0})$ dengan probabilitas 0,000 ( $\mathrm{p}$-value $<0,05)$ sehingga Ho ditolak. Data menunjukkan bahwa ada perbedaan yang signifikan antara nilai hasil belajar kognitif sebelum penerapan buku Basic Reading dan setelah menerapkan buku teks. Berdasarkan nilai rata-rata nilai pretes yaitu 63,63 dan nilai postes 80,61, dapat disimpulkan bahwa hasil belajar kognitif mahasiswa meningkat. Peningkatan pembelajaran kognitif yang berkaitan dengan analisis $N$-Gain diketahui bahwa kategorisasi peningkatan kognitif pada hasil belajar adalah cukup sehingga skor pretes dan postes berbeda. Hasil T-Test (Paired Samples T-Test) menunjukkan perbedaan yang signifikan; hasilnya dipertajam dengan peningkatan nilai kognitif pretest dan posttest.

Selain itu, hasil softskills mahasiswa juga menunjukkan bahwa nilai-nilai etika inti mahasiswa telah berubah secara signifikan. Sebelum menerapkan buku bacaan dasar, para mahasiswa sering melakukan tugas mereka secara individu yang membuat mereka sering melakukan kecurangan. Itu juga menghalangi rasa kerja sama mereka. Selanjutnya, para mahasiswa juga terlambat menyerahkan tugas mereka yang disebabkan oleh kurangnya motivasi mereka dalam membaca dan kadang-kadang mereka tidak melakukan tugas. Buku Basic Reading dikembangkan untuk menanamkan nilai-nilai etika kepada para mahasiswa pada jurusan Pendidikan Bahasa Inggris 
STKIP PGRI Sumatera Barat. Nilai-nilai karakter yang tertanam dalam buku ini didasarkan pada nilai-nilai karakter yang dikembangkan dalam Kurikulum Pendidikan Indonesia. Hasil observasi menunjukkan bahwa setelah menggunakan buku ini, nilai-nilai sosial mahasiswa bisa meningkat. Mereka menjadi mahasiswa yang lebih disiplin, bertanggung jawab, dan saling menghormati. Dalam melakukan tugas mereka, mereka sering melakukan kerja sama dan saling membantu. Artinya meskipun penerapan buku teks ini tidak banyak memberikan pengaruh yang signifikan terhadap nilai karakter mahasiswa, tetapi dapat menanamkan nilai etis mahasiswa. Hal ini sejalan dengan hasil penelitian yang dilakukan oleh Isgandi \& Prasodjo (2018) yang menyatakan bahwa dalam merealisasikan pendidikan karakter yang digagas oleh pemerintah, pembentukan karakter dan pembiasaan akhlak mulia adalah cara yang dapat dilakukan dalam pendidikan sehingga keterkaitan antar elemen bersifat menyeluruh. Dengan kata lain, pendidikan karakter diberikan beriringan dan sejalan dengan pengajaran pengetahuan lainnya.

Hasil nilai $\mathrm{N}$-Gain menjelaskan penggunaan buku bacaan dasar dalam mata pelajaran membaca berdampak pada peningkatan keterampilan berpikir mahasiswa. Meningkatnya keterampilan berpikir mahasiswa baik dari softskills dan hardskills disebabkan oleh materi buku yang terkandung dalam pendidikan karakter yang berdampak pada peningkatan softskills mahasiswa dan juga penggunaan multimodality yang dapat membuat mahasiswa tertarik dan memahami teks yang mereka baca sehingga meningkatnya rasa ingin tahu mereka pada suatu topik dalam belajar membaca. Hasil penelitian ini menunjukkan penggunaan buku bacaan dasar dapat meningkatkan hasil belajar mahasiswa.

Hasil belajar kognitif dikategorikan sebagai kriteria cukup yang dilihat dari dari hasil belajar dengan menggunakan buku teks Basic Reading yang memungkinkan mahasiswa untuk meningkatkan keterampilan membaca mereka. Hal ini disebabkan oleh isi buku teks ini terdiri dari keterampilan dasar membaca seperti memahami topik, memahami paragraf, menggunakan petunjuk konteks, pemindaian, membaca sekilas, dan mempratinjau. Buku pelajaran ini mengarahkan mahasiswa untuk dapat melatih keterampilan membaca mereka. Hal ini juga diatur untuk mempertajam keterampilan membaca mahasiswa yang sudah dimiliki. Mereka diberi pengetahuan dan kemudian mereka diminta untuk menerapkan keterampilan mereka dalam latihan yang terkandung dalam buku ini. Latihan-latihan ini mengarahkan mahasiswa untuk memecahkan masalah untuk menanamkan nilai-nilai pendidikan karakter. Ini juga bertujuan untuk membangun mahasiswa untuk berpikir kritis, kreatif, dan inovatif dalam menyelesaikan masalah yang berkaitan dengan lingkungan sekitar mereka. Hasil penelitian ini menunjukkan bahwa penerapan buku Basic Reading dapat meningkatkan keterampilan membaca mahasiswa.

Terlebih lagi, implementasi buku teks ini membuat mahasiswa memperoleh pengalaman belajar berbeda yang mereka dapatkan dari pembelajaran sebelumnya. Mereka juga dapat berinteraksi dengan teman sebaya, bekerja sama dalam mengungkapkan pendapat, dan melakukan diskusi dalam memecahkan masalah. Buku ini disusun dalam desain yang tidak rumit dan mudah untuk memahami teks yang disajikan dengan banyak ilustrasi dalam bentuk gambar sebagai contoh dan latihan yang menjelaskan materi yang terkandung dalam buku teks.

Berdasarkan hasil dan pembahasan di atas, dapat disimpulkan bahwa buku teks Basic Reading efektif digunakan. Hal ini dapat dilihat pada hasil perhitungan $N$-Gainyang didapat dari peningkatan tes belajar kognitif sebesar 0,43 yang dikategorikan sebagai 'Sedang'. Hasil T-test juga menunjukkan bahwa ada perbedaan yang signifikan antara pretest dan skor posstest kemampuan membaca mahasiswa yang berarti buku teks Basic Reading dapat meningkatkan kemampuan membaca mahasiswa secara efektif. Selanjutnya, hasilnya juga menunjukkan bahwa nilai etis mahasiswa meningkat setelah penerapan buku ini yang terintegrasi dengan pendidikan karakter. Hal ini terlihat dari mahasiswa yang lebih aktif dan percaya diri dalam mengikuti perkuliahan serta disiplin dan bertanggung jawab dalam melaksanakan tugas. Hasil ini didukung dengan pernyataan oleh Abidin (2012) bahwa dalam pendidikan, pendidikan karakter dapat diintegrasikan dalam proses pembelajaran, bahan ajar, dan model pembelajaran. 


\section{Evaluation}

Tahap terakhir pada penelitian ini adalah tahap evaluasi. Pada tahap ini, tim peneliti menganalisa respon peserta didik dan pendidik terhadap penggunaan buku ajar Basic Reading tersebut. Untuk mendapatkan respon peserta didik dan pendidik, tim peneliti menggunakan kuisioner dan wawancara. Dalam kuesioner, peneliti menggunakan 15 pernyataan yang terkait dengan indikator dan dibagi menjadi beberapa pernyataan sebagai sub indikator, multimodalityyang terdiri dari gambar, variasi penulisan, diagram, tabel, ujaran, dan nilai-nilai pendidikan karakter dan nilai-nilai pendidikan karakter. Kemudian, latihan dan kegiatan memiliki beberapa sub indikator juga seperti: memfasilitasi untuk memahami teks, menuntut pemikiran kritis, dan memberikan nilai-nilai pendidikan karakter. Selanjutnya, daya tarik dan tampilan buku memiliki beberapa sub indikator seperti: Sampul menarik, gambar menarik, dan daya tarik dalam memberikan kesenangan membaca.

Peneliti mendapatkan data melalui wawancara kepada peserta didik, peneliti menganalisis jawaban peserta didik tentang pernyataan yang diberikan pada waktu wawancara kemudian membuat hasilnya. Respon peserta didik terhadap buku ajar Basic Reading tentang gambar mengatakan bahwa gambar dalam buku teks Basic Reading membantu mahasiswa untuk mudah memahami dan membuat buku teks menjadi lebih menarik bagi mahasiswa. Gambar-gambar tersebut menarik bagi mahasiswa karena banyak mahasiswa merasa bosan membaca teks tanpa gambar, keberadaan gambar dalam buku teks memainkan peran penting dan bermanfaat bagi mereka untuk membantunya dalam memahami teks yang dimulai ketika membaca teks. Membaca teks dalam buku teks diawali oleh daya tarik gambar. Ketika mahasiswa membaca teks dengan gambar-gambar, sebagian besar mahasiswa merasa bahwa mereka dibantu oleh gambar dalam memahami sebuah teks. Hasil wawancara dengan pendidik menunjukkan bahwa gambar yang terdapat pada buku ajar tersebut memudahkan peserta didik dan pendidik untuk memahami teks yang terdapat pada buku ajar tersebut, akan tetapi gambar yang terdapat pada buku ini lebih digunakan untuk menarik minat mahasiswa untuk membaca. Hal ini didukung dengan pendapat dari Weninger (2020) yang menyatakan bahwa penggunaan multimodal dalam sebuah teks memberikan multi makna pada pembaca sehingga pembaca dapat memahami dan menganalisa teks tersebut berdasarkan makna gambar dan makna bacaan.

Sedangkan variasi penulisan sangat berguna bagi mahasiswa untuk meyakinkan pembaca agar dapat mengambil poin utama dengan mudah dari teks. Dari data di atas, mahasiswa mengatakan bahwa variasi penulisan membantu mahasiswa belajar dengan menggunakan buku Basic Reading karena variasi tulisan membedakan poin penting dalam teks. Mahasiswa juga mengatakan bahwa variasi penulisan sangat membantu karena menarik untuk dibaca dan membantu dalam memahami teks yang dibaca. Sedangkan respon pendidik terhadap variasi tulisan yang ada pada buku ajar Basic Reading ini sangat membantu dalam memahami teks dan membedakan poin-poin penting yang terdapat dalam teks.

Respon peserta didik terhadap diagram dan tabel yang terdapat pada buku ajar Basic Reading menunjukkan bahwa diagram dan tabel membantu mahasiswa dalam memudahkan dan memahami isi teks. Memahami banyak jenis teks biasanya tidak mudah, tetapi di sini mahasiswa mengatakan bahwa teks itu mudah dimengerti karena diagram dan tabel. Ini berarti bahwa teks perlu dijelaskan oleh diagram dan tabel untuk membuat teks berisi contoh detail seperti dalam tampilan tabel dan diagram. Peserta didik juga mengatakan bahwa diagram dan tabel tidak banyak membantu peserta didik atau itu biasa karena peserta didik mengatakan pemborosan, kurang pengertian, tidak dapat memahami diagram, dan bentuk seperti yang dinyatakan pada jawaban. Sedangkan respon pendidik terhadap diagram dan tabel yang terdapat pada buku ajar ini sangat membantu dalam memahami isi teks.

Kemudian, bagian terakhir dari multimodality dalam buku teks ini adalah ujaran. Persepsi mahasiswa terhadap ujaran menunjukkan bahwa pertama, mahasiswa mengatakan ujaran itu mudah dipahami. Kedua, mahasiswa mengatakan ujaran sulit dipahami dan ketiga, mahasiswa 
mengatakan ujaran biasa. Pertama, sebagian besar mahasiswa mengatakan bahwa ujaran itu mudah dimengerti karena ujaran itu jelas, menggunakan kosa kata yang terkenal, menggunakan kata yang mudah, bisa misalnya, melatih membaca dan menarik. Sedangkan respon dari pendidik mengatakan bahwa ujaran yang terdapat pada buku ajar ini sudah sesuai dengan kemampuan peserta didik sehingga peserta didik tidak kesulitan dalam memahami kosakata atau ujaran tersebut.

Sub indikator berikutnya adalah nilai-nilai pendidikan karakter. Data menunjukkan bahwa nilai-nilai pendidikan karakter yag terdapat dalam buku tersebut bermanfaat bagi mahasiswa. Nilainilai pendidikan karakter penting dan berguna karena dapat memengaruhi kehidupan dan mengarahkan pada perilaku positif. Inilah pengalaman yang dirasakan mahasiswa ketika belajar dengan membaca buku teks Basic Reading ini. Ini berarti bahwa dosen menggunakan buku Basic Reading akan secara otomatis membimbing mahasiswa untuk mendapatkan nilai-nilai pendidikan karakter dengan menggunakan buku teks karena apa yang terkandung dalam buku teks dan apa yang diminta dalam buku teks untuk mencapai nilai pendidikan karakter dalam kehidupannya. Hal ini sejalan dengan penelitian yang dilakukan oleh Padmadewi (2015) yang menyatakan bahwa dalam pengajaran pendidikan karakter, nilai karakter yang ingin dikembangkan dan dibentuk dalam diri mahasiswa diberikan secara implisit dimana nilai tersebut disisipkan dalam pembelajaran dan dikuatkan dengan implementasi perangkat pembelajaran seperti silabus, buku, dan RPS sehingga mahasiswa tidak menyadari pembelajaran pendidikan karakter ini.

Mahasiswa mengatakan, nilai pendidikan karakter bermanfaat karena menambah pengetahuan. Nilai pendidikan karakter berguna bagi mahasiswa dalam meningkatkan pengetahuan mahasiswa tentang karakter. Di sini, jelas menunjukkan bahwa buku pelajaran Basic reading dengan nilai-nilai pendidikan karakter dapat menambah pengetahuan mahasiswa untuk tahu lebih banyak mengetahui tidak hanya bahasa Inggris dan keterampilannya tetapi juga pengetahuan tentang nilai sosial yang dinyatakan dalam nilai-nilai pendidikan karakter. Ketika mahasiswa merasa pengetahuan mahasiswa meningkat, itu berarti buku Basic Reading tepat untuk meningkatkan pendidikan karakter.Mahasiswa juga mengatakan, nilai-nilai pendidikan karakter penting karena menuntut pemikiran kritis, kreativitas dalam memahami buku teks reading.

Dari data di atas, terlihat bahwa nilai-nilai pendidikan karakter penting bagi mahasiswa untuk memiliki nilai-nilai yang baik seperti, kreatif, tanggung jawab, kepedulian sosial dan saling membantu. Dari pernyataan ini, mahasiswa menilai bahwa nilai-nilai pendidikan karakter memberi manfaat bagi mahasiswa dalam belajar menggunakan buku Basic Reading. Dari jawaban tersebut, terdapat variasi pernyataan yang dikatakan oleh mahasiswa, umumnya bermanfaat dalam memberikan nilai pendidikan karakter karena nilai pendidikan karakter penting, mengajarkan halhal positif kepada mahasiswa, dapat diterapkan dalam kehidupan sehari-hari dan dalam proses pembelajaran.

\section{SIMPULAN}

Berdasarkan penelitian yang telah dilakukan, ditemukan bahwa dalam mata kuliah Reading belum tersedia buku ajar kredibel dan berbasis pendidikan karakter. Hasil analisa kebutuhan menunjukkan bahwa baik dosen maupun mahasiswa membutuhkan buku ajar yang dapat memotivasi dan meningkatkan minat baca. Selain itu, buku ajar tersebut sebaiknya menggunakan multimodality dan berbasis pendidikan karakter. Hasil penelitian juga menunjukkan buku ajar Basic Reading yang dikembangkan telah layak untuk digunakan dalam proses perkuliahan sebagaimana hasil penilaian yang dilakukan oleh ahli dan praktisi. Hasil uji praktikalitas dan uji validitas menunjukkan bahwa buku ini dapat digunakan sebagai buku ajar dalam mata kuliah Basic Reading. Kelayakan dari buku ajar ini juga didukung oleh hasil uji coba terbatas yang menunjukkan respon positif dari peserta didik dalam menggunakan buku ajar Basic Reading. Penggunaan buku ajar Basic Reading ini meningkatkan baik hardskills maupun softskills peserta didik sehingga buku ajar ini dapat meningkatkan kemampuan membaca peserta didik dan meningkatkan kemampuan 
softskills yaitu karakter peserta didik. Hal inilah yang diperlukan dalam menciptakan kondisi pembelajaran atau perkuliahan yang menunjang baik hardskills maupun softskills perserta didik. Peneliti merekomendasikan bahwa alat pembelajaran seperti buku teks memainkan peran penting dalam proses belajar mengajar pada mata kuliah membaca. Isi buku teks harus dirancang dengan menarik dan kreatif untuk mendorong peserta didik menumbuhkan kecintaan membaca. Juga disarankan agar buku teks yang dirancang harus mengintegrasikan pendidikan karakter tidak hanya dalam proses pengajaran tetapi juga dalam materi pengajaran untuk menghasilkan karakter muda yang baik.

\section{DAFTAR PUSTAKA}

Abdullah, R. (2017). Pembelajaran Dalam Perspektif Kreativitas Guru Dalam Pemanfaatan Media Pembelajaran. Lantanida Journal, 4(1), 35-49. https://doi.org/10.22373/lj.v4i1.1866

Abidin, Y. (2012). Model Penilaian Otentik Dalam Pembelajaran Membaca Pemahaman Beroreintasi Pendidikan Karakter. Jurnal Pendidikan Karakter, $0(2), \quad$ Article 2. https://doi.org/10.21831/jpk.v0i2.1301

Bahtiar, E. T. (2015). Penulisan Bahan Ajar. https://doi.org/10.13140/RG.2.1.1441.6083

Callow, J., \& Callow, J. (2013). The shape of text to come. Primary English Teaching Association Australia (PETAA).

Hermawan, B. (2013). Multimodality: Menafsir Verbal, Membaca Gambar,Dan Memahami Teks. Jurnal Pendidikan Bahasa Dan Sastra, 13(1), 19-28. https://doi.org/10.17509/bs_jpbsp.v13i1.756

Hidayah, Y. F., Siswandari, \& Sudiyanto. (2017). Pengembangan Media Komik Digital Akuntansi Pada Materi Menyusun Laporan Rekonsiliasi Bank Untuk Siswa Smk-Neliti. Jurnal Pendidikan Dan Kebudayaan, 2(2), 239-250. https://doi.org/10.24832/jpnk.v2i2.588

Isgandi, Y., \& Prasodjo, P. (2018). Pengembangan Buku Ajar Pendidikan Agama Islam Berbasis Pendidikan Karakter Dan Jiwa Nasionalis. TARBAWY: Indonesian Journal of Islamic Education, 5(2), 97-110. https://doi.org/10.17509/t.v5i2.16735

Jalil, A. (2016). Karakter Pendidikan untuk Membentuk Pendidikan Karakter. Nadwa, 6(2), 175-194. https://doi.org/10.21580/nw.2012.6.2.586

Jewitt, C., Bezemer, J., \& O’Halloran, K. (2016). Introducing Multimodality. Routledge.

Kurt, G. (2017). Implementing the Flipped Classroom in Teacher Education: Evidence from Turkey. Journal of Educational Technology \& Society, 20(1), 211-221.

Kuswono, K. (2013). Character Education Muhammadiyah Pattern (Case Study SMA Muhammadiyah 1 And Ma Muallimin Yogyakarta). Guidena: Jurnal Ilmu Pendidikan, Psikologi, Bimbingan dan Konseling, 3(1), 42-49. https://doi.org/10.24127/gdn.v3i1.374

Lestariningsih, N., \& Suardiman, S. P. (2017). Pengembangan Bahan Ajar Tematik-Integratif Berbasis Kearifan Lokal Untuk Meningkatkan Karakter Peduli Dan Tanggung Jawab. Jurnal Pendidikan Karakter, 7(1), Article 1. https://doi.org/10.21831/jpk.v7i1.15503

Normawati, N. (2015). Nilai Pendidikan Karakter Dalam Buku Teks Pelajaran Bahasa Indonesia SMP Di Daerah Istimewa Yogyakarta. Jurnal Pendidikan Karakter, O(1), Article 1. https://doi.org/10.21831/jpk.v0i1.8612

Nurrita, T. (2018). Pengembangan Media Pembelajaran Untuk Meningkatkan Hasil Belajar Siswa. MISYKAT: Jurnal Ilmu-ilmu Al-Quran, Hadist, Syari'ah dan Tarbiyah, 3(1), 171. https://doi.org/10.33511/misykat.v3n1.171

Padmadewi, N. N. (2015). Pengembangan Perangkat Pembelajaran Berbasis Pendidikan Karakter Untuk Mata Kuliah Strategi Pembelajaran Bahasa Jurusan Pendidikan Bahasa Jepang Di 
Universitas Pendidikan Ganesha Singaraja. JPI (Jurnal Pendidikan Indonesia), 4(1), Article 1. https://doi.org/10.23887/jpi-undiksha.v4i1.4893

Palila, S. (2012). Analisis Kebutuhan Karakter Mahasiswa Psikologi Fakultas Ilmu Sosial Dan Humaniora UIN Sunan Kalijaga Yogyakarta. Humanitas, 12(2), 13. https://doi.org/10.26555/humanitas.v12i2.3838

Pawitasari, E., Mujahidin, E., \& Fattah, N. (2015). Pendidikan Karakter Bangsa dalam Perspektif Islam (Studi Kritis Terhadap Konsep Pendidikan Karakter Kementerian Pendidikan \& Kebudayaan). Ta'dibuna: Jurnal Pendidikan Islam, 4(1), 1-20. https://doi.org/10.32832/tadibuna.v4i1.573

Putri, N. A. (2011). Penanaman Nilai-Nilai Pendidikan Karakter Melalui Mata Pelajaran Sosiologi. KOMUNITAS: International Journal of Indonesian Society and Culture, 3(2), Article 2. https://doi.org/10.15294/komunitas.v3i2.2317

Sesmiyanti, S., Antika, R., \& Yulmiati, Y. (2018). Persepsi Mahasiswa Tentang Pendidikan Karakter pada Buku Teks Reading di Perguruan Tinggi Swasta. Pena : Jurnal Pendidikan Bahasa Dan Sastra, 7(2), 1-19. https://doi.org/10.22437/pena.v7i2.5289

Setyosari, P. D. H. P. (2016). Metode Penelitian Pendidikan \& Pengembangan. Prenada Media.

Walsh, M. (2011). Multimodal Literacy: Researching Classroom Practice. Primary English Teaching Association. https://acuresearchbank.acu.edu.au/item/8q7v0/multimodal-literacyresearching-classroom-practice

Weninger, C. (2020). Multimodality in Critical Language Textbook Analysis. Language, Culture and Curriculum, O(0), 1-14. https://doi.org/10.1080/07908318.2020.1797083

Winiharti, M., \& Herlina, C. (2016). Audio only or Video?: Multimodality for Listening Comprehension. 189-192. https://doi.org/10.2991/conaplin-16.2017.41

Yulian, R., \& Yuniarti, Y. (2019). Pengembangan Bahan Ajar Business English Berbasiskan Pendekatan Multimodality Dan Authentic Materials. Pena Kreatif: Jurnal Pendidikan, 8(2), 143-154. https://doi.org/10.29406/jpk.v8i2.1870

Zheng, L., Yang, J., Cheng, W., \& Huang, R. (2014). Emerging approaches for supporting easy, engaged and effective collaborative learning. Journal of King Saud University - Computer and Information Sciences, 26(1, Supplement), 11-16. https://doi.org/10.1016/j.jksuci.2013.10.002 